\title{
Rearing Conditions and Foot-Pad Dermatitis in Swedish Turkey Poults
}

\author{
By C. Ekstrand and B. Algers
}

Department of Animal Environment and Health, Faculty of Veterinary Medicine, Swedish University of Agricultural Sciences, Skara, Sweden.

\begin{abstract}
Ekstrand, C. and B.Algers: Rearing conditions and foot-pad dermatitis in Swedish turkey poults. Acta vet. scand. 1997, 38 167-174. - A method previously developed for classification of broiler foot health status was used in order to estimate the prevalence of foot-pad dermatitis in Swedish turkey poults. Data on foot health were collected from 53 commercial turkey flocks at slaughter. The producers were asked to fill in a questionnaire on rearing conditions and equipment for every flock.

Lesions were very commonly observed, only $2 \%$ of the feet were classified as being without lesions, $78 \%$ had mild lesions (discoloration, erosions), and $20 \%$ had severe lesions (ulcers). There was a significant $(p<0.01)$ effect of litter material on the presence of severe foot-pad dermatitis, flocks reared on straw showing higher prevalence than flocks reared on wood shavings. There was also a significant $(\mathrm{p}<0.001)$ effect of the type of water system, severe foot-pad dermatitis being more common in flocks reared in houses equipped with bell drinkers compared with flocks reared with small cups. The addition of extra litter during the rearing period resulted in significantly $(p<0.01)$ lower prevalence of lesions compared with flocks where no extra litter had been added.
\end{abstract}

housing; welfare; litter; water; stocking density; ulcer; erosion.

\section{Introduction}

The main research areas regarding poultry welfare in Sweden have so far been confined to different housing systems for laying hens and the stocking density for broiler chickens. Very little has been done to investigate or improve the welfare of turkey poults, and the turkey industry in Sweden is relatively small. Since 1988 the Swedish Poultry Meat Association has run a regulatory programme with the aim of maintaining a high and uniform level of technological and management quality in broiler production (Ekstrand 1993), a programme which is approved and monitored by the Swedish Board of Agriculture. In order to find a suitable variable showing how the birds' environmental conditions have affected them during the rearing period, Ekstrand et al. (in press) developed a method of classifying broiler foot health status. During the course of this work, it was decided that the same type of investigations should be made for the turkey production.

The occurrence of foot-pad dermatitis in Swedish turkey production has not been studied previously, and almost no data from other countries have been reported. The feet are not used for human consumption, and thus not of direct economical importance. However, lesions on the feet may be a gateway for bacteria causing impairment of carcass quality. In severe cases the lesions may also cause pain to the birds, which together with a deteriorated state of health constitutes a welfare issue. 
Foot-pad dermatitis in broilers is a thoroughly described problem. It is a type of contact dermatitis (Greene et al. 1985) affecting the plantar regions of the feet. Discoloration of the skin is seen, often in combination with hyperkeratosis and necrosis of the epidermis, leading to erosions. In more severe cases, these changes are followed by ulcerations with inflammatory reactions of the subcutaneous tissue. The ulcerations are often covered by crusts formed by litter and faecal material. In broiler chickens, the dermatitis is thought to be caused by a combination of wet litter, high ammonia content and other chemical factors in the litter (Nairn \& Watson 1972, Harms et al. 1977, Greene et al. 1985, Martland 1985).

The lesions on turkey feet are very similar to the ones seen in broilers. Martland (1984) studied the lesions on turkeys under experimental conditions, and has described how early lesions, like morphological changes in the reticular skin pattern, later develop into papillae. In severe cases inflammatory reactions, necrosis and the forming of scabs are seen. The lesions mainly affect the metatarsal pad, but may in severe cases also involve the digital pads of the turkeys' feet.

Earlier research has been directed mainly towards the effect of different feed compositions on the incidence of foot-pad dermatitis in turkey poults (Patrick et al. 1942, McGinnis \& Carver 1947, Richardson \& Wilgus 1967, Jensen et al. 1970). For example, it has been shown that there is an increase in the incidence of footpad dermatitis when the birds are fed diets deficient in biotin (Harms et al. 1977), and that extra methionine added to the diet will reduce the incidence (Chavez \& Kratzer 1972, 1974). As with the broiler chickens, litter condition seems to play an important role. Several studies have identified a correlation between damp and/or crusty litter and foot-pad dermatitis ( $A b$ - bott et al. 1969, Charles \& Fortune 1977, Harms \& Simpson 1977, Martland 1984).

The main aim of this cross sectional observational study was to investigate how rearing conditions influence the occurrence and severity of foot-pad dermatitis in commercially-grown poults. Another aim was to investigate if the judgement criteria used for classifying foot-pad dermatitis in broilers (Ekstrand et al. in press) could be used also for turkeys. If so, this would facilitate the build up of a future turkey foot health monitoring programme.

\section{Materials and methods}

Study design

The study was designed as a cross-sectional, observational study. From Sweden's total of approximately 15 major commercial turkey farms, 10 were sampled by using a table of random numbers and a numbered list of all farms. Data were collected from all flocks from these farms during the study period, giving a total of 53 flocks. We considered the geographical location, size of farm and standard of equipment to be representative for Swedish turkey farms in general. The hybrid used was British United Turkey (BUT), and the planned stocking density for the flocks in this study varied between 15 and $35 \mathrm{~kg} / \mathrm{m}^{2}$. By random, $60 \%$ of the flocks included in the study were male flocks, and $40 \%$ were female flocks. Any mixed flocks were excluded from the study.

The collecting of data started in April 1994 and ended in November the same year. From each flock 100 pairs of feet were selected by systematic random sampling at slaughter. The assistants at the abattoirs were instructed to collect 2 times 50 pairs by taking every tenth pair of feet at one occasion during the beginning of a batch and once during the end. The feet were then sent in for central classification. The rearers filled in a simple questionnaire about rearing conditions 
conditions and general health status for each flock. The slaughter houses reported age at slaughter, flock weight and downgradings/condemnations.

\section{Classification of lesions}

The sampled turkey feet were all examined macroscopically by the same observer. The examination was blind, i.e. the observer did not know the identity of the flock at the time of the examination, although knowing which feet belonged to the same flock was unavoidable. The foot-pad status was classified in 6 different classes according to a protocol primarily designed for broilers by Ekstrand and Svedberg (Ekstrand et al. in press). The classes were as follows: 1) no visible lesions: smooth epidermis, no discoloration; 2) papillae only: hyperkeratosis but no discoloration; 3) mild/superficial lesions: discoloration or erosions in the epidermal layer; 4) mild/superficial lesions and papillae: hyperkeratosis and discoloration or erosions in the epidermal layer; 5) severe ulcerations: discoloration, ulcers and signs of inflammatory reactions, and 6) severe ulcerations and papillae: discoloration, hyperkeratosis, ulcers and signs of inflammatory reactions.

The different types of lesions were grouped, forming 3 major classes: A) no lesions; B) mild lesions: discoloration, papillae and/or erosions; and C) severe lesions: discoloration, papillae and ulcers. In some of the analyses presented here, $\mathrm{B}$ and $\mathrm{C}$ were further combined into one group: D) lesions.

\section{Data analysis}

The prevalence of foot pad dermatitis was calculated, and the proportion of some of the variables concerning rearing methods was calculated.

The unit in the analytic procedures was the flock. Subsequent analysis involved pooling of rearing condition categories into gradations of practical relevance to the turkey industry. Data were analysed using the two-tailed t-test, with a confidence level of $95 \%$. A two-tailed linear regression technique (General Linear Models Procedure; GLM) (SAS Institute Inc. 1989) was used at the $95 \%$ level to investigate associations or interactions between the different variables at flock level.

\section{Results}

\section{Descriptive results}

The birds. The planned stocking density for the flocks in this study was between 15 and 35 $\mathrm{kg} / \mathrm{m}^{2}$, and the real stocking density when calculated from total flock weight at slaughter varied between 14 and $36 \mathrm{~kg} / \mathrm{m}^{2}$. The poults were between 59 and 76 days old at slaughter.

The rearing conditions. All flocks were reared indoors in climate controlled houses of the same basic construction. All flocks were fed commercial turkey diet with the same basic content, although delivered by several different feed manufacturers.

The types of litter used are presented in Table 1. For $80 \%$ of the flocks the farmers reported that extra litter material had been added during the rearing period. The litter was always cleaned out between every batch.

The flocks were generally classified as healthy by the farmers, and no outbreaks of acute diarrhoea or diseases were reported from any flock (all flocks were tested for Salmonella). This was supported by the reports from the slaughter houses. All flocks were given anti-coccidials (monensin) in the feed. No growth promoting substances were used in any flock, and no flocks were otherwise medicated.

The foot-pad lesions. Very few birds were without foot-pad lesions (Table 2): $78 \%$ of the feet were classified as having mild lesions, 
Table 1. Rearing conditions (litter material and water supply) for turkey flocks.

\begin{tabular}{llc}
\hline Variable & Definition & $\begin{array}{c}\text { Frequency } \\
\text { (\% of flocks) }\end{array}$ \\
\hline Litter material & $\begin{array}{l}\text { wood shavings (in some cases mixed with a } \\
\text { smaller proportion of chopped barley straw) } \\
\text { rape straw }\end{array}$ & 62 \\
& wheat straw & 36 \\
Litter depth at day one & 5 cm or less & 2 \\
& more than 5 cm & 85 \\
Litter added during the & yes & 15 \\
rearing period & no & 80 \\
Water supply & small cups & 20 \\
& water bells & 49 \\
\hline
\end{tabular}

Table 2. Prevalence of foot-pad lesions in turkey poults at slaughter in Sweden, 1994.

\begin{tabular}{lc}
\hline & prevalence (\%) \\
\cline { 2 - 2 } & foot \\
\hline A: no visible lesions & 2 \\
B: mild lesions only & 78 \\
Papillae only & 7 \\
Mild/superficial lesions & 10 \\
Mild/superficial lesions and papillae & 61 \\
C: severe lesions & 20 \\
Severe ulcerations & 6 \\
Severe ulcerations and papillae & 14 \\
\hline
\end{tabular}

and $20 \%$ as having severe lesions. $77 \%$ of the birds had exactly the same type of lesions on both feet, and no birds had lesions that were of totally different severity, i.e. one foot-pad classified as ' $A$ ' and the other one as ' $C$ '.

The variation between farms and flocks in the prevalence of severe foot pad dermatitis was large. The mean flock prevalence was $27.9 \pm$ 15.7 (st. dev.), ranging from $1 \%$ to $78 \%$.
Analyses

As lesions were found on $98 \%$ of the foot-pads examined in this study, the analyses on effects of rearing conditions on the prevalence of lesions were concentrated on the severe lesions (category 'C').

There was a significant $(\mathrm{p}=0.0001)$ effect of water equipment (Table 3 ). Flocks reared in houses equipped with water bells had higher prevalence of foot-pad dermatitis than flocks reared with small cups.

Litter material significantly $(\mathrm{p}<0.01)$ influenced the prevalence of foot-pad dermatitis. Flocks reared on wood shavings had lower prevalence of foot-pad dermatitis than flocks reared on rape or wheat straw. There was also a significant $(p<0.01)$ effect of litter being added during the rearing period: the flocks which did not get any new litter material had higher prevalence at time of slaughter.

Litter depth at day one did not significantly affect the prevalence of foot-pad dermatitis in the poults, and there was no significant interaction between litter material and litter depth. A re- 
Table 3. Effect of rearing condition variables on the prevalence of severe foot pad dermatitis at time of slaughter in turkey poults.

\begin{tabular}{|c|c|c|c|}
\hline Variable & $\begin{array}{l}\text { Exposure } \\
\text { level }\end{array}$ & $\begin{array}{c}\text { Mean prevalence } \\
\quad \pm \text { st.dev. }\end{array}$ & $\begin{array}{l}\text { Statistical } \\
\text { significance } \\
\text { (p) }\end{array}$ \\
\hline Type of water system & $\begin{array}{l}\text { small cups } \\
\text { water bells }\end{array}$ & $\begin{array}{l}18.1 \pm 11.3 \\
34.7 \pm 15.4\end{array}$ & 0.0001 \\
\hline Type of litter & $\begin{array}{l}\text { wood shavings } \\
\text { rape or wheat straw }\end{array}$ & $\begin{array}{l}22.1 \pm 14.3 \\
36.5 \pm 13,9\end{array}$ & 0.0011 \\
\hline Litter added during the rearing period & $\begin{array}{l}\text { yes } \\
\text { no }\end{array}$ & $\begin{array}{l}23.5 \pm 13.3 \\
44.8 \pm 14.5\end{array}$ & 0.0020 \\
\hline Real stocking density & $\begin{array}{l}14-30 \mathrm{~kg} / \mathrm{m}^{2} \\
30-36 \mathrm{~kg} / \mathrm{m}^{2}\end{array}$ & $\begin{array}{l}29.2 \pm 16.3 \\
22.1 \pm 14.4\end{array}$ & 0.13 \\
\hline Planned stocking density & $\begin{array}{l}15-30 \mathrm{~kg} / \mathrm{m}^{2} \\
30-35 \mathrm{~kg} / \mathrm{m}^{2}\end{array}$ & $\begin{array}{l}33.9 \pm 13.2 \\
24.7 \pm 17.1\end{array}$ & 0.15 \\
\hline Litter depth & $\begin{array}{l}5 \mathrm{~cm} \text { or less } \\
\text { more than } 5 \mathrm{~cm}\end{array}$ & $\begin{array}{l}26.4 \pm 15.4 \\
31.0 \pm 11.1\end{array}$ & 0.37 \\
\hline Sex & $\begin{array}{l}\text { male } \\
\text { female }\end{array}$ & $\begin{array}{l}27.0 \pm 17.2 \\
29.7 \pm 12.9\end{array}$ & 0.54 \\
\hline Age of slaughter & $\begin{array}{l}59-67 \text { days } \\
68-76 \text { days }\end{array}$ & $\begin{array}{l}25.8 \pm 18.7 \\
27.3 \pm 13.6\end{array}$ & 0.74 \\
\hline
\end{tabular}

gression model showed that 'farm', i.e. producer, significantly influenced the prevalence of foot pad dermatitis $(\mathrm{p}<0.05)$.

Neither planned nor real stocking density significantly affected the foot-pad status of the poults, and there was no significant effect of age at slaughter or sex.

The results of the GLM procedure showed no biologically relevant interactions between any of the factors analysed at the $95 \%$ significance level.

\section{Discussion}

One of the aims of this study was to investigate if a method for quick macroscopical classification of foot-pad lesions originally developed for broilers could also be used for turkey poults. The lesions in poults showed to be of the same type, which made this possible. The scoring appears to be worth using in regular health monitoring programmes, as is currently done for broilers (Ekstrand et al. in prep). As a majority of the birds showed the same foot-pad status on both feet, we conclude that it will in future investigations only be necessary to examine one foot per bird if the purpose is to get a general impression of the foot health status of a flock. This study indirectly supports other research about a strong association between poor litter conditions and foot-pad dermatitis (Harms \& Simpson 1977, Geraedts 1983, Martland 1984). The litter conditions are a result of both housing methods, technical equipment and management factors. Litter material is one such factor, and in this study flocks reared on wood shavings were found to have significantly lower prevalence of foot-pad dermatitis than flocks 
reared on straw. Other types of contact dermatitis, such as so called "breast buttons" (focal ulcerative dermatitis; FUD) and "scabby hocks", partly have the same background as the foot-pad lesions and are also correlated to wet litter (Martland 1984, Gonder \& Barnes 1987). Tilley et al. (1990) found an effect of litter type on the incidence of FUD, birds raised on coarse shavings having a higher incidence than birds reared on soft, good quality shavings. The prevalence of these lesions was not recorded in the present study.

Litter management is a very important factor in preventing foot-pad dermatitis (Abbott et al. 1969). Charles \& Fortune (1977) showed that the use of new shavings each week reduced foot-pad lesions compared to unchanged litter. In an investigation of commercial Dutch turkey farms, Geraedts (1983) found that a combination of regular top-dressing and cultivating the litter yielded the best litter quality in practice, and that there was a correlation between litter conditions and the prevalence of foot-pad lesions. Abbott et al. (1969) described how an increase in temperature between the 6th and 8th week made the litter dry up and the incidence of foot-pad dermatitis almost disappear. In our study extra litter was added during the rearing period for $80 \%$ of the flocks, and these flocks had significantly lower levels of severe footpad dermatitis than the flocks which did not get any new litter. However, the mean prevalence in the former flocks was still as high as $23.5 \%$, which means that only adding extra litter during the rearing period is not sufficient to prevent the disease. Compared to broiler chickens, turkey poults are known to be less prone to scratch in the litter (Hale \& Schein 1962, Hughes \& Grigor 1996), and thus less active in helping to ventilate the litter layer during the rearing period. This may be a part of the explanation to why this kind of foot-pad dermatitis is more common in turkey than in broilers.
In broilers, investigations have shown an effect of different types of water equipment on litter quality (Elson 1989, Tucker \& Walker 1992). Our study indicates that this is the case also for turkey poults, as a significant difference in the prevalence of foot-pad dermatitis was found when comparing small cups and bell drinkers. The water spillage from large bell-type drinkers is likely to be larger than the spillage from small cups, and therefore more likely to cause wet areas in the litter.

Other studies have shown that a high stocking density results in greater moisture in the litter (Noll et al. 1991), which could be expected to result in a higher prevalence of foot-pad dermatitis. This has also been shown to be the case in broiler rearing, where Gaardbo Thomsen (1992) has found a correlation between increased stocking density and litter quality deterioration, and in the same study also an increase in the incidence of foot-pad lesions as stocking density was increased. However, stocking density did not significantly affect foot-pad status in this present study. A possible explanation for this could be that the producers who choose to rear their poults at relatively high stocking densities are the ones that have the most modern houses with the best ventilation capacity, thus ventilating the litter better. This has not been further investigated.

All flocks in our study were fed the same type of modern commercial diet, which suggests that the very high prevalence of severe foot-pad dermatitis in some of the flocks was not related to dietary deficiencies. However, a diet which is nutritionally well balanced but otherwise not optimal may still cause sticky droppings and wet or crusty litter, and thus affect the birds' foot-pad status. As feed was delivered from several different feed manufacturers, there is a possibility of differences in feed quality and feed raw materials, which may have had an effect on the litter quality. This was not further investigated in this study. 
No association between sex and the prevalence of foot-pad lesion was found. This is in accordance with Martland (1984), who in experimental studies found no effect of sex or body weight on foot-pad status.

The findings of a very high prevalence of footpad dermatitis should raise questions from a welfare point of view (Hocking 1993). The lesions may in mild cases not be of direct harm to the birds, but it is reasonable to assume that the severe cases are at least uncomfortable and most likely painful. Nevertheless, it is very difficult to identify lameness caused by foot-pad dermatitis in a commercial flock. As birds with foot-pad dermatitis usually get the same kind of lesions on both feet, severely affected birds are rarely seen limping, but are instead more likely to move less. Geraedts (1983) found a correlation between the incidence of leg weakness (defined as difficulty to walk) in general and the incidence of foot-pad injuries, but this finding was not further analysed. As a consequence of the lack of distinct clinical symptoms of footpad dermatitis alone the economic significance of the disease is probably underestimated (Martland 1984).

The results of this study indicate that the prevalence of foot-pad dermatitis in meat turkey flocks is, at least partly, linked to the litter contiditon. This suggests that the prevalence of foot-pad dermatitis could be used as an indicator of the standard of rearing and stockmanship.

\section{Acknowledgements}

The authors thank Jan Svedberg for valuable ideas and discussions on the classification of lesions, and Linda Keeling for comments on the manuscript. This project was funded by the Swedish Poultry Meat Association (Svensk Fågel) and the Swedish University of Agricultural Sciences.

\section{References}

Abbott WW, Couch JR, Atkinson RL: The incidence of foot-pad dermatitis in young turkeys fed high levels of soybean meal. Poult. Sci. 1969, 48, 218688.

Charles $\mathrm{OW}$, Fortune J: The influence of diet and litter management on foot-pad lesions in turkey poults. Poult. Sci. 1977, 56, 1348.

Chavez E, Kratzer FH: Prevention of foot-pad dermatitis in poults with methionine. Poult. Sci. $1972,51,1545-48$.

Chavez E, Kratzer FH: Effect of diet on foot-pad dermatitis in poults. Poult. Sci. 1974, 53, 755-60.

Ekstrand C: Effects of stocking density on the health, behaviour and productivity of broilers. Report 32, Department of Animal Hygiene, Swedish University of Agricultural Sciences, 1993, 46 pp.

Ekstrand $C$, Algers B, Svedberg S: Rearing conditions and foot-pad dermatitis in Swedish broiler chickens. Prev. Vet. Med. 1997 (in press).

Ekstrand C, Carpenter T, Andersson I, Algers B: Prevalence and prevention of foot-pad dermatitis in broilers in Sweden. (In prep.).

Elson HA: Drinker design affects litter quality. Misset World Poultry, 1989, 1, 8-9.

Geraedts LHJ: Leg disorders caused by litter conditions and the influence of the type of litter and of litter cultivations on the results of turkeys. Turkeys, 1983, vol. 31, number 5, pp 20-25.

Gonder E, Barnes HJ: Focal ulcerative dermatitis ("Breast Buttons") in marketed turkeys. Avian Dis., 1987, 31, pp 52-58.

Greene JA, McRacken RM, Evans RT: A contact dermatitis of broilers - clinical and pathological findings. Avian Path., 1985, 14, 23-38.

Hale EB, Scein $M W$ : The behaviour of turkeys. In: Hafez, E.S.E. (ed): The behaviour of domestic animals, Balliere, Tindall and Cox, London 1962, pp 531-564.

Harms RH, Damron BL, Simpson CF:Effect of wet litter and supplemental biotin and/or whey on the production of foot-pad dermatitis in broilers. Poult. Sci. 1977, 56, 291-296.

Harms $R H$, Simpson $C F$ : Influence of wet litter and supplemental biotin on foot-pad dermatitis in turkey poults. Poult. Sci. 1977, 56, 2009-12.

Hocking PM: Welfare of turkeys. Proc. Fourth European Symposium on Poultry Welfare, Edinburgh, 1993. pp 125-138.

Hughes $B O$, Grigor PN: Behavioural time-budgets and beak related behaviour in floor-housed turkeys. Anim. Welf. 1996, 5, 189-198. 
Jensen LS, Martinson R, Schumaier G: A foot-pad dermatitis in turkey poults associated with soybean meal. Poult. Sci. 1970, 49, 76-82.

Martland MF: Wet litter as a cause of plantar pododermatitis, leading to foot ulceration and lameness in fattening turkeys. Avian Path. 1984, 13, 241-52.

Martland MF: Ulcerative dermatitis in broiler chickens: the effect of wet litter. Avian Path. 1985, 14, 353-364.

McGinnis J, Carver JS: The effect of riboflavin and biotin in prevention of dermatitis and perosis in turkey poults. Poult. Sci. 1947, 26, 364-71.

Nairn ME, Watson ARA: Leg weakness of poultry - a clinical and pathological characterisation. Aust. Vet. J. 1972, 48, 645-656.

Noll SL, El Halawani ME, Waibel PE, Redig P, Janni $K$ : Effect of diet and population density on male turkeys under various environmental conditions. Poult. Sci. 1991, 70, 923-34.

Patrick H, Boucher RV, Butcher RA, Knandel HC: The nutritional significance of biotin in chick and poultry nutrition. Poult. Sci. 1942, 21, 476.

Richardson CE, Wilgus HS: Biotin - a limiting factor in turkey rations? Feedstuffs, 1967, 39, pp 52-54.

Tilley BJ, Barnes HJ, Rives DV, Gerig TM: Effects of litter type on focal ulcerative dermatitis ("breast buttons") in male turkeys. Poult. Sci. 1990, 69, (suppl. 1) 195.

Tucker SA, Walker AW: Hock burn in broilers. In: Garnsworthy PC, Haresign W, Cole DJA (Eds):
Recent advances in animal nutrition. Butterworth Heinemann, Oxford. 1992, pp 33-49.

\section{Sammanfattning \\ Effekter av uppfödningsmiljön på förekomsten av fot- skador hos svenska kalkoner.}

En metod som tidigare utvecklats för klassificering av fotskador hos slaktkyckling användes för att uppskatta prevalensen av trampdynedermatit hos svenska slaktkalkoner. Uppgifter om fothälsan insamlades från 53 kommersiellt uppfödda kalkonflockar i samband med slakt. För varje flock fick uppfödarna fylla i ett formulär med uppgifter om uppfödningsmiljön och utrustningen i den aktuella avdelningen. Fotskador var mycket vanligt förekommande, endast $2 \%$ av kalkonfötterna klassificerades som "utan anmärkning", $78 \%$ hade lindriga skador (missfärgning, erosioner) och $20 \%$ uppvisade grava skador (ulcerationer). Det fanns en signifikant $(\mathrm{p}<0.01)$ effekt av strömaterial på förekomsten av grava fotskador; flockar som fötts upp på halmströbädd hade högre förekomst än flockar uppfödda på kutterspån. De flockar som fătt tillskott av nytt strömaterial under uppfödningsperiodens gång uppvisade signifikant $(\mathrm{p}<0.01)$ lägre prevalens av grava fotskador än de som inte fătt något extra strömaterial. Vi såg även en signifikant $(\mathrm{p}<0.001)$ effekt av typ av vattensystem, grava fotskador var vanligare hos flockar som fötts upp i anläggningar med stora vattenklockor än hos flockar som fötts upp med små vattenkoppar.

(Received December 10, 1996; accepted February 14, 1997).

Reprints may be obtained from: C. Ekstrand, Department of Animal Environment and Health, Faculty of Veterinary Medicine, Swedish University of Agricultural Sciences, P.O. Box 234, S-532 23 Skara, Sweden. E-mail: Lotta.Ekstrand@hmh.slu.se, tel: +4651167 207, fax: +4651167204. 